\title{
The influence of herbicides combined with mechanical treatments on weed infestation, growth and yield of onion (Allium cepa L.)
}

\author{
Wpływ łączenia ochrony chemicznej z zabiegami mechanicznymi \\ na zachwaszczenie, wzrost i plony cebuli (Allium cepa L.)
}

Małgorzata Kohut, Zbigniew Anyszka, Joanna Golian

\begin{abstract}
Summary
Field experiments were carried out in 2010-2012 at the Research Institute of Horticulture in Skierniewice. The aim of this studies was to determine the response of drilled onion and weeds to herbicides combined with mechanical treatments, in comparison to the usages of herbicides and the impact of weed management methods on the weed infestation and the yield of onion. During the experiments the following herbicides were used: pendimethalin applied after sowing of onion or after emergences in mixture with bromoxynil, glyphosate pre-emergence and bromoxynil and oxyfluorofen post-emergence. Mechanical treatments were conducted at 2-4 and 3-5 leaves stage of onion. Studies shown that weed control depended on herbicides and their rates. Mechanical treatments performed after herbicides application caused strong reduction of infestation and advantageously influenced on the yield of onion. The highest yields were obtained from plots with regular hand weeded and after chemical weed control including the use of pendimethalin after sowing, glyphosate pre-emergence and bromoxynil post-emergence, with the split application method.
\end{abstract}

Key words: drilled onion; weed control; herbicides; mechanical treatments

\section{Streszczenie}

W latach 2010-2012, w Instytucie Ogrodnictwa w Skierniewicach przeprowadzono badania polowe, których celem było określenie reakcji cebuli z siewu i chwastów na herbicydy stosowane w połączeniu z zabiegami mechanicznymi, w porównaniu do zastosowania samych herbicydów oraz wpływu tych systemów ochrony na ograniczenie zachwaszczenia i plonowanie cebuli. Do badań użyto następujące herbicydy: pendimetalinę, stosowaną po siewie oraz po wschodach w mieszaninie z bromoksynilem, glifosat przed wschodami oraz oksyfluorofen i bromoksynil, po wschodach cebuli. Zabiegi mechaniczne przeprowadzano w fazie 2-4 i 3-5 liści cebuli. Badania wykazały, że stopień zniszczenia chwastów przez herbicydy, w zakresie użytych dawek, był zróżnicowany. W systemach obejmujących zabiegi mechaniczne, wykonywane po zastosowanych wcześniej herbicydach, zanotowano bardzo silne ograniczenie zachwaszczenia pierwotnego i wtórnego oraz korzystny wpływ na plonowanie cebuli. Najwyższe plony uzyskano z obiektów systematycznie pielonych ręcznie oraz odchwaszczanych chemicznie z użyciem pendimetaliny po siewie, glifosatu przed wschodami i bromoksynilu metodą dawek dzielonych, po wschodach rośliny uprawnej.

Słowa kluczowe: cebula z siewu; chwasty; herbicydy; zabiegi mechaniczne

\author{
Instytut Ogrodnictwa \\ Oddział Warzywnictwa \\ Pracownia Herbologii \\ Konstytucji 3 Maja 1/3, 96-100 Skierniewice \\ malgorzata.kohut@inhort.pl
}




\section{Wstęp / Introduction}

Cebula (Allium cepa L.) jest rośliną bardzo wrażliwą na zachwaszczenie i wymaga skutecznych metod zapobiegania i zwalczania chwastów (Dobrzański 1999). Do ograniczania zachwaszczenia zaleca się metodę integrowana, w której wykorzystuje się różne sposoby zwalczania chwastów (Dobrzański 1994, 1998), przy czym stosowanie herbicydów jest jednym z najważniejszych czynników ograniczania strat plonów (Pałczyński i wsp. 2001, 2002). Istotną rolę w integrowanej ochronie przed chwastami wielu gatunków warzyw odgrywają zabiegi agrotechniczne, wykonywane zarówno przed uprawą, jak i w trakcie okresu wegetacyjnego, przy użyciu nowoczesnych maszyn i narzędzi (Adamczewski i Dobrzański 1997; Fogelberg i Kritz 1999; Bond i Grundy 2001; Autko i Moisevich 2006; Mahmood Khokhar i wsp. 2006; Zbytek i Talarczyk 2008; Van der Weide i wsp. 2008; Adamczewski i Dobrzański 2012).

W uprawie ekologicznej zaleca się bronowanie cebuli przed wschodami oraz po wschodach, od fazy 3-4 liści właściwych, ale efekt chwastobójczy tych zabiegów jest krótkotrwały. W ochronie integrowanej bronowanie cebuli przed wschodami jest rzadko stosowane, gdyż jest mało efektywne i musi być uzupełniane herbicydami (Dobrzański i Adamczewski 2006; Pałczyński i Dobrzański 2007), natomiast korzystne może być zastosowanie herbicydów przed wschodami i wcześnie po wschodach cebuli oraz przeprowadzenie mechanicznych zabiegów odchwaszczających. W takim systemie najczęściej herbicydy stosuje się metodą dawek dzielonych (Dobrzański i wsp. 1992; Dobrzański 1994). Zabiegi mechaniczne, wykonywane po wcześniej zastosowanych herbicydach, powodują przemieszczanie nasion chwastów w glebie i pobudzają je do kiełkowania, ale jednocześnie powodują wzruszanie gleby i usuwanie skorupy glebowej (Dobrzański i Adamczewski 2006). Zabiegi mechaniczne w międzyrzędziach zaleca się wykonywać możliwie płytko, aby nie uszkadzać korzeni cebuli i nie wyciagać głębiej położonych nasion chwastów (Dobrzański 1994, 1998). Wprowadzenie zabiegów mechanicznych do systemu ochrony cebuli przed chwastami pozwala ograniczyć ilość stosowanych herbicydów, ale jednocześnie zabiegi te mogą osłabiać skuteczność herbicydów i skracać okres ich działania.

Celem badań było określenie reakcji cebuli z siewu i chwastów na herbicydy i uzupełniające zabiegi mechaniczne, w porównaniu do samych herbicydów oraz wpływu połączonych metod ochrony na ograniczenie zachwaszczenia i plonowanie cebuli.

\section{Materiały i metody / Materials and methods}

Badania nad łączonym stosowaniem herbicydów z zabiegami mechanicznymi w cebuli z siewu przeprowadzono w latach 2010-2012, w Instytucie Ogrodnictwa w Skierniewicach. Doświadczenia zakładano metodą losowanych bloków, w 4 powtórzeniach, na glebie płowej, utworzonej $\mathrm{z}$ utworów piaskowych, klasy IVa, zawierającej 1,3-1,5\% substancji organicznych, pH 6,5. Wielkość poletek wyno- siła 12,15 $\mathrm{m}^{2}$. Cebulę, odmiany Błońska, wysiewano w dniach 15.04.2010, 18.04.2011 i 20.04.2012, w rzędy w rozstawie $45 \mathrm{~cm}$, w ilości 45 sztuk nasion na 1 metr bieżący rzędu. Do badań użyto następujące herbicydy: pendimetalinę (Stomp 330 EC), glifosat (Roundup 360 SL), oksyfluorofen (Galigan 240 EC) i bromoksynil (Emblem $20 \mathrm{WP}$ ). Pendimetalinę stosowano po siewie, w dawce $1155 \mathrm{~g} /$ ha lub w fazie 1-2 liści cebuli, w dawce $990 \mathrm{~g} / \mathrm{ha} \mathrm{w}$ mieszaninie $\mathrm{z}$ bromoksynilem (100 g/ha). Glifosat użyto w dawce $720 \mathrm{~g} / \mathrm{ha}$, na 2-3 dni przed wschodami, a oksyfluorofen i bromoksynil metodą dawek dzielonych, po wschodach cebuli. Oksyfluorofen stosowano dwukrotnie: w fazie liścieni - 1 liścia cebuli w dawce 7,2 g/ha, na chwasty w fazie liścieni oraz po 5-7 dniach w dawce $12 \mathrm{~g} / \mathrm{ha}$. Bromoksynil stosowano w dawce $100 \mathrm{~g} / \mathrm{ha} \mathrm{w}$ uproszczonym systemie odchwaszczania, po wcześniej użytym glifosacie, wykonując zabieg w fazie liścieni-1 liścia cebuli, na chwasty $\mathrm{w}$ fazie liścieni lub w trzech zabiegach, z których pierwszy wykonywano w fazie 1-2 liści cebuli (100 g/ha) i kolejne co 8 dni, w dawkach odpowiednio 150 i 200 g/ha. Herbicydy aplikowano kołowym opryskiwaczem poletkowym na sprężone powietrze, wyposażonym w rozpylacze płaskostrumieniowe DG Tee Jet 110-02 VS. Zabiegi mechaniczne wykonywano dwukrotnie: $w$ fazie 2-4 i 3-5 liści cebuli, przy użyciu pielnika P 430/2, zaopatrzonego w noże kątowe, gęsiostópki, wałki strunowe. Pierwszy zabieg przypadał po 42-46, a drugi po 54-70 dniach od pierwszego opryskiwania bromoksynilem. W czasie zabiegów glebę wzruszano na głębokość 2-4 cm.

Stopień zniszczenia chwastów oceniano szacunkowo w \%, a liczbę i masę chwastów określano metodą ramkową, po 2-3 dniach od drugiego zabiegu mechanicznego. Fitotoksyczność dla cebuli oceniano po 42-43 i 57-63 dniach od pierwszego zabiegu bromoksynilem. Liczbę roślin cebuli określano w szt./mb rzędu, po zakończeniu wschodów rośliny uprawnej. Przed zbiorem, po 126-149 dniach wegetacji, określono zachwaszczenie wtórne w \%, obsadę roślin cebuli w rzędach oraz załamanie szczypioru w \%. Zbiory cebuli przeprowadzano jednorazowo w dniach 7.09.2010, 14.09.2011 i 29.08.2012, w fazie dojrzałości zbiorczej. Cebulę dosuszano, obcinano szczypior, sortowano i określano wysokość plonów poszczególnych klas wielkości, a następnie obliczano plon ogólny i handlowy cebuli $\mathrm{w} \mathrm{kg} / 100 \mathrm{~m}^{2}$. Wyniki plonów poddano analizie statystycznej $\mathrm{w}$ oparciu o program analizy wariancji dla doświadczenia jednoczynnikowego, wykorzystujący test Newmana-Keulsa do oceny różnic między średnimi, przy poziomie istotności 5\%.

\section{Wyniki i dyskusja / Results and discussion}

Cebula była silnie zachwaszczona gatunkami dwuliściennymi, średnie pokrycie gleby przez chwasty na kontroli wynosiło $61 \%$ (tab. 1). Wyniki badań wykazały, że stopień zniszczenia chwastów ogółem przez herbicydy, zależał od zastosowanego środka. Najsilniej niszczone były chwasty po zastosowaniu glifosatu przed wschodami i bromoksynilu metodą dawek dzielonych (w pierwszym zabiegu $\mathrm{W}$ mieszaninie $\mathrm{z}$ pendimetaliną) po wschodach 
Tabela 1. Zniszczenie ważniejszych gatunków chwastów w cebuli z siewu, w zależności od metody ochrony (ocena po 2-3 dniach od drugiego zabiegu mechanicznego)

Table 1. Main weed species control in drilled onion, depending on weed management method (evaluation at 2-3 days after 2nd mechanical treatment)

\begin{tabular}{|c|c|c|c|c|c|c|c|c|c|c|c|}
\hline \multirow{2}{*}{$\begin{array}{l}\text { Metody ochrony przed chwastami, } \\
\text { terminy stosowania herbicydów } \\
\text { Weed management methods, } \\
\text { terms of herbicides application }\end{array}$} & \multirow{2}{*}{$\begin{array}{l}\text { Dawka } \\
\text { Rate } \\
\text { [g/ha] }\end{array}$} & \multicolumn{10}{|c|}{$\begin{array}{c}\text { Stopień zniszczenia gatunków chwastów - Weed species control } \\
{[\%]}\end{array}$} \\
\hline & & $\frac{\tilde{0}}{0.0}$ & 默 & 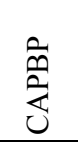 & $\begin{array}{l}\text { 岁 } \\
\text { 点 } \\
\end{array}$ & 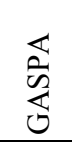 & 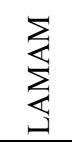 & 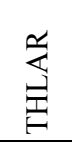 & $\sum_{\substack{\mathrm{I} \\
\mathrm{s}}}$ & 光 & 式 \\
\hline Pendimethalin $\left(T_{1}\right)+$ glyphosate $\left(T_{2}\right)$ & $1155+720$ & 91,0 & 96,3 & 77,8 & 100 & 28,3 & 100 & 30,0 & 23,0 & 100 & 85,0 \\
\hline $\begin{array}{l}\text { Pendimethalin }\left(T_{1}\right)+\text { glyphosate }\left(T_{2}\right) \\
\text { Pielenia mechaniczne }- \text { mechanical } \\
\text { treatments }(2 \times)\end{array}$ & $1155+720$ & 99,5 & 100 & 98,4 & 100 & 97,5 & 100 & 100 & 100 & 100 & 100 \\
\hline Glyphosate $\left(\mathrm{T}_{2}\right)+$ oxyfluorfen $\left(\mathrm{T}_{3}, \mathrm{~T}_{4}\right)$ & $720+7,2+12$ & 45,0 & 36,3 & 35,0 & 98,0 & 63,3 & 76,5 & 100 & 53,8 & 86,3 & 36,3 \\
\hline $\begin{array}{l}\text { Glyphosate }\left(\mathrm{T}_{2}\right)+\text { oxyfluorfen }\left(\mathrm{T}_{3}, \mathrm{~T}_{4}\right) \\
\text { Pielenia mechaniczne }- \text { mechanical } \\
\text { treatments }(2 \times)\end{array}$ & $720+7,2+12$ & 98,1 & 99,3 & 99,2 & 100 & 96,3 & 100 & 100 & 100 & 100 & 100 \\
\hline Glyphosate $\left(\mathrm{T}_{2}\right)+$ bromoxynil $\left(\mathrm{T}_{3}\right)$ & $720+100$ & 65,8 & 50,0 & 79,3 & 48,8 & 99,0 & 94,3 & 100 & 100 & 100 & 0 \\
\hline $\begin{array}{l}\text { Glyphosate }\left(\mathrm{T}_{2}\right)+\text { bromoxynil }\left(\mathrm{T}_{3}\right) \\
\text { Pielenia mechaniczne }- \text { mechanical } \\
\text { treatments }(2 \times)\end{array}$ & $720+100$ & 99,2 & 98,3 & 100 & 99,3 & 100 & 98,2 & 100 & 100 & 100 & 100 \\
\hline $\begin{array}{l}\text { Glyphosate }\left(\mathrm{T}_{2}\right) \\
+\operatorname{bromoxynil}\left(\mathrm{T}_{5}, \mathrm{~T}_{6}, \mathrm{~T}_{7}\right)\end{array}$ & $\begin{array}{c}720+ \\
100+150+ \\
200\end{array}$ & 71,3 & 57,0 & 98,0 & 46,3 & 100 & 95,3 & 100 & 95,5 & 90,0 & 10,0 \\
\hline $\begin{array}{l}\text { Glyphosate }\left(\mathrm{T}_{2}\right) \\
+(\text { bromoxynil }+ \text { pendimethalin })\left(\mathrm{T}_{5}\right) \\
+ \text { bromoxynil }\left(\mathrm{T}_{6}, \mathrm{~T}_{7}\right)\end{array}$ & $\begin{array}{c}720+ \\
(100+990) \\
150+200\end{array}$ & 94,0 & 97,5 & 100 & 88,8 & 100 & 100 & 100 & 100 & 100 & 35,0 \\
\hline Pielenie ręczne - Hand weeding & - & 100 & 100 & 100 & 100 & 100 & 100 & 100 & 100 & 100 & 100 \\
\hline $\begin{array}{l}\text { Kontrola - pokrycie gleby przez chwas } \\
\text { Check - ground cover by weeds [\%] }\end{array}$ & & 61,0 & 12,5 & 17,8 & 4,4 & 5,1 & 2,9 & 4,1 & 2,4 & 8,0 & 3,8 \\
\hline
\end{tabular}

$\mathrm{T}_{1}$ - po siewie - after sowing; $\mathrm{T}_{2}-2-3$ dni przed wschodami $-2-3$ days before emergences; $\mathrm{T}_{3}-\mathrm{w}$ fazie liścieni-1 liść - at cotyledon-1 leaf stage; $\mathrm{T}_{4}-$ po 5-7 dniach od $\mathrm{T}_{3}-5-7$ days after $\mathrm{T}_{3} ; \mathrm{T}_{5}-\mathrm{w}$ fazie 1-2 liści - at 1-2 leaves stage; $\mathrm{T}_{6}-$ po 8 dniach od $\mathrm{T}_{5}-8$ days after $\mathrm{T}_{5} ; \mathrm{T}_{7}-$ po 8 dniach od $\mathrm{T}_{6}-8$ days after $\mathrm{T}_{6}$ treatment

CHEAL - Chenopodium album, CAPBP - Capsella bursa-pastoris, URTUR - Urtica urens, GASPA - Galinsoga parviflora, LAMAM - Lamium amplexicaule, THLAR - Thlaspi arvense, SENVU - Senecio vulgaris, MATIN - Matricaria inodora, ECHCG - Echinochloa crus-galli

cebuli (94\%), a także po użyciu pendimetaliny po siewie cebuli i glifosatu przed wschodami (91\%). Najsłabszy efekt chwastobójczy zanotowano po zastosowaniu glifosatu przed wschodami i oksyfluorofenu w dwóch dawkach (45\%), średni po użyciu glifosatu i po wschodach bromoksynilu w jednym zabiegu $(65,8 \%)$ lub w trzech zabiegach (71,3\%). Wyniki pokazują, że największy wpływ na zniszczenie chwastów miało zastosowanie pendimetaliny. Substancja ta działa doglebowo i przez długi okres hamuje kiełkowanie i wschody chwastów, pozostałe środki charakteryzują się krótkotrwałym działaniem. Zastosowanie herbicydów $\mathrm{w}$ połączeniu $\mathrm{z}$ zabiegami mechanicznymi powodowało zniszczenie chwastów w ponad 98\%, niezależnie od zastosowanego środka.

Całkowicie niszczone były takie gatunki chwastów, jak: tobołki polne (Thlaspi arvense), starzec zwyczajny (Senecio vulgaris), maruna bezwonna (Matricaria inodora) i chwastnica jednostronna (Echinochloa crus-galli). Herbicydy stosowane w doświadczeniach niszczyły chwasty w krytycznym okresie konkurencji, który, jak podaje Dobrzański (1999), obejmuje okres od wschodów do 3-4 liści cebuli. Brak chwastów w tym okresie najsilniej wpływa na plonowanie cebuli. Włączenie zabiegów mechanicznych do systemu ochrony cebuli przed chwastami pozwalało na zmniejszenie zużycia herbicydów oraz ograniczenie liczby wykonywanych opryskiwań. Według Dobrzańskiego i Adamczewskiego (2009) pielenie ręczne jest kosztowne, dlatego też zasadniczą rolę w strategii niechemicznego regulowania zachwaszczenia powinny pełnić zabiegi mechaniczne i fizyczne, wykonywane przed siewem $\mathrm{i}$ interwencyjne w czasie wegetacji roślin.

W doświadczeniach, liczba i masa niezniszczonych chwastów były zróżnicowane i zależały od metody odchwaszczania. W cebuli traktowanej po siewie pendimetalina, przed wschodami glifosatem i dwukrotnie pielonej mechanicznie po wschodach, zanotowano największą redukcję liczby chwastów $(90,2 \%)$, podczas gdy same herbicydy, bez zabiegów mechanicznych, redukowały liczbę chwastów w 78,9\% (tab. 2). Podobnie kształtowała się liczba chwastów po użyciu przed wschodami glifosatu i po wschodach bromoksynilu, w trzech zabiegach.

Najwięcej chwastów wystapiło w cebuli traktowanej przed wschodami glifosatem i po wschodach oksyfluorofenem (redukcja liczby chwastów tylko o $29,4 \%$ ). W cebuli odchwaszczanej tymi samymi środkami i pielonej mechanicznie, redukcja liczby chwastów wynosiła już ponad $58 \%$, a więc tyle samo, ile po zastosowaniu 
Tabela 2. Liczba i masa chwastów ogółem oraz fitotoksyczność dla cebuli, w zależności od metody ochrony przed chwastami

Table 2. Total number and biomass of weeds and phytotoxicity to onion, depending on weed management method

\begin{tabular}{|c|c|c|c|c|c|c|c|}
\hline \multirow{2}{*}{$\begin{array}{l}\text { Metody ochrony przed chwastami, } \\
\text { terminy stosowania herbicydów } \\
\text { Weed management methods, } \\
\text { terms of herbicides application }\end{array}$} & \multirow{2}{*}{$\begin{array}{l}\text { Dawka } \\
\text { Rate } \\
{[\mathrm{g} / \mathrm{ha}]}\end{array}$} & \multicolumn{2}{|c|}{$\begin{array}{l}\text { Liczba chwastów ogółem } \\
\text { Total number of weeds }\end{array}$} & \multicolumn{2}{|c|}{$\begin{array}{l}\text { Masa chwastów ogółem } \\
\text { Total biomass of weeds }\end{array}$} & \multicolumn{2}{|c|}{$\begin{array}{c}\text { Fitotoksyczność } \\
\text { Phytotoxicity } \\
{[\%]} \\
\end{array}$} \\
\hline & & $\begin{array}{l}{\left[\mathrm{szt} . / \mathrm{m}^{2}\right]} \\
{\left[\mathrm{pcs} / \mathrm{m}^{2}\right]}\end{array}$ & $\begin{array}{l}\text { redukcja } \\
\text { reduction } \\
\quad[\%]\end{array}$ & {$\left[\mathrm{g} / \mathrm{m}^{2}\right]$} & $\begin{array}{l}\text { redukcja } \\
\text { reduction } \\
\quad[\%]\end{array}$ & $42-43 *$ & $57-63^{*}$ \\
\hline Pendimethalin $\left(T_{1}\right)+$ glyphosate $\left(T_{2}\right)$ & $1155+720$ & 48,9 & 78,9 & 547,9 & 74,8 & 0,4 & 0,2 \\
\hline $\begin{array}{l}\text { Pendimethalin }\left(T_{1}\right)+\text { glyphosate }\left(T_{2}\right) \\
\text { Pielenia mechaniczne }- \text { mechanical } \\
\text { treatments }(2 \times)\end{array}$ & $1155+720$ & 22,8 & 90,2 & 106,8 & 95,1 & 0 & 0 \\
\hline Glyphosate $\left(T_{2}\right)+$ oxyfluorfen $\left(T_{3}, T_{4}\right)$ & $720+7,2+12$ & 163,6 & 29,4 & 1159,2 & 46,6 & 0,3 & 0,1 \\
\hline $\begin{array}{l}\text { Glyphosate }\left(\mathrm{T}_{2}\right)+\text { oxyfluorfen }\left(\mathrm{T}_{3}, \mathrm{~T}_{4}\right) \\
\text { Pielenia mechaniczne }- \text { mechanical } \\
\text { treatments }(2 \times)\end{array}$ & $720+7,2+12$ & 96,4 & 58,4 & 240,6 & 88,9 & 0,1 & 0 \\
\hline Glyphosate $\left(\mathrm{T}_{2}\right)+$ bromoxynil $\left(\mathrm{T}_{3}\right)$ & $720+100$ & 96,1 & 58,5 & 1064,1 & 51,0 & 0,3 & 0,2 \\
\hline $\begin{array}{l}\text { Glyphosate }\left(\mathrm{T}_{2}\right)+\text { bromoxynil }\left(\mathrm{T}_{3}\right) \\
\text { Pielenia mechaniczne }- \text { mechanical } \\
\text { treatments }(2 \times)\end{array}$ & $720+100$ & 48,8 & 78,9 & 146,6 & 93,3 & 0,3 & 0,2 \\
\hline $\begin{array}{l}\text { Glyphosate }\left(\mathrm{T}_{2}\right) \\
+\operatorname{bromoxynil}\left(\mathrm{T}_{5}, \mathrm{~T}_{6}, \mathrm{~T}_{7}\right)\end{array}$ & $\begin{array}{l}720+ \\
100+150+ \\
200\end{array}$ & 26,3 & 88,6 & 769,2 & 64,6 & 0,2 & 0,1 \\
\hline $\begin{array}{l}\text { Glyphosate }\left(\mathrm{T}_{2}\right) \\
+(\text { bromoxynil }+ \text { pendimethalin })\left(\mathrm{T}_{5}\right) \\
+ \text { bromoxynil }\left(\mathrm{T}_{6}, \mathrm{~T}_{7}\right)\end{array}$ & $\begin{array}{c}720+ \\
(100+990) \\
150+200\end{array}$ & 24,4 & 89,5 & 358,9 & 83,5 & 0,5 & 0,1 \\
\hline Pielenie ręczne - Hand weeding & - & 0 & 100 & 0 & 100 & 0 & 0 \\
\hline Kontrola - Check & - & 231,8 & 0 & 2172,2 & 0 & 0 & 0 \\
\hline
\end{tabular}

$\mathrm{T}_{1}$ - po siewie - after sowing; $\mathrm{T}_{2}-2-3$ dni przed wschodami $-2-3$ days before emergence; $\mathrm{T}_{3}-\mathrm{w}$ fazie liścienie-1 liść - at cotyledon-1 leaf stage; $\mathrm{T}_{4}-$ po 5-7 dniach od $\mathrm{T}_{3}-5-7$ days after $\mathrm{T}_{3} ; \mathrm{T}_{5}-\mathrm{w}$ fazie 1-2 liści - at 1-2 leaves stage; $\mathrm{T}_{6}-$ po 8 dniach od $\mathrm{T}_{5}-8$ days after $\mathrm{T}_{5} ; \mathrm{T}_{7}-$ po 8 dniach od zabiegu $\mathrm{T}_{6}-8$ days after $\mathrm{T}_{6}$ treatment

*liczba dni od pierwszego zabiegu bromoksynilem - days after 1st bromoxynil treatment

glifosatu przed wschodami i jednego zabiegu bromoksynilem, bez zabiegów mechanicznych. Badania Pałczyńskiego i Dudka (2003) nad skutecznością kilku sposobów stosowania herbicydów, uzupełnionych zabiegami ręcznymi i mechanicznymi, przeprowadzanymi przy użyciu wielorzędowego pielnika zawieszanego P430/2 wykazały, że najkorzystniejszym sposobem zwalczania chwastów było zastosowanie pendimetaliny bezpośrednio po siewie, propachloru i glifosatu przed wschodami cebuli oraz oksyfluorofenu w dawkach dzielonych i uzupełnienie ich zabiegami mechanicznymi. Taki system odchwaszczania najkorzystniej wpływał na plonowanie cebuli.

Świeża masa chwastów w poszczególnych obiektach nie była tak zróżnicowana, jak ich liczba. Redukcja masy chwastów przez same herbicydy wahała się od 46,6 do $74,8 \%$, oprócz cebuli opryskiwanej glifosatem, bromoksynilem $\mathrm{z}$ pendimetaliną $\mathrm{i}$ samym bromoksynilem (redukcja masy o $83,5 \%$ ), natomiast po wykonaniu zabiegów mechanicznych wahała się w granicach 88,9-95,1\%.

Po zastosowaniu herbicydów zaobserwowano niewielkie objawy fitotoksyczności na roślinach cebuli, jednak miały one charakter przemijający (tab. 2). Przed zbiorem obsada roślin cebuli $\mathrm{w}$ rzędach kształtowała się podobnie we wszystkich badanych obiektach i była wyższa niż na kontroli (tab. 3). Dojrzewanie cebuli wiąże się z odpowiednim wykształceniem cebul i załamywaniem szczy- pioru. W doświadczeniach szczypior cebuli załamywał się nierównomiernie, a stopień załamania przed zbiorem był zależny od systemu ochrony przed chwastami. Najsilniej załamany był szczypior u cebuli pielonej ręcznie $(95,4 \%)$, nieco słabiej po zastosowaniu glifosatu z bromoksynilem, uzupełnionych dwukrotnym pieleniem mechanicznym (91\%), po zastosowaniu pendimetaliny, glifosatu i mechanicznego pielenia $(90,7 \%)$, a także glifosatu $\mathrm{z}$ bromoksynilem, $\mathrm{z}$ dodawaną $\mathrm{w}$ pierwszym zabiegu pendimetaliną $-89,4 \%$ (tab. 3).

Obsada roślin cebuli w rzędach, oceniana szacunkowo w \% przed zbiorem, była równomierna na wszystkich obiektach odchwaszczanych, a różnice nie przekraczały 3\% (tab. 3). Mniejszą obsadę zanotowano jedynie na kontroli, co spowodowane było wyrywaniem młodych roślin cebuli razem $\mathrm{z}$ chwastami $\mathrm{w}$ czasie pielenia. Połączenie metody chemicznej $\mathrm{z}$ pieleniem mechanicznym skuteczniej ograniczało zachwaszczenie wtórne w cebuli. Największą redukcję zachwaszczenia przed zbiorem cebuli zaobserwowano po wykonaniu zabiegów mechanicznych poprzedzonych użyciem pendimetaliny po siewie i glifosatu przed wschodami rośliny uprawnej $(69,3 \%)$ oraz po zastosowaniu glifosatu przed wschodami i bromoksynilu w fazie liścieni-1 liścia cebuli $(63,1 \%)$.

Stwierdzono wyraźne różnice w plonowaniu cebuli, w zależności od zastosowanego systemu odchwaszczania. 
Tabela 3. Wpływ metody ochrony przed chwastami na załamanie szczypioru, obsadę cebuli i zachwaszczenie wtórne

Table 3. The influence of weed management method on leaves fall down, onion density before harvest and secondary weed infestation

\begin{tabular}{|c|c|c|c|c|}
\hline $\begin{array}{l}\text { Metody ochrony przed chwastami, } \\
\text { terminy stosowania herbicydów } \\
\text { Weed management methods, } \\
\text { terms of herbicides application }\end{array}$ & $\begin{array}{l}\text { Dawka } \\
\text { Rate } \\
\text { [g/ha] }\end{array}$ & $\begin{array}{c}\text { Załamanie } \\
\text { szczypioru } \\
\text { Onion eaves } \\
\text { fall down } \\
{[\%]}\end{array}$ & $\begin{array}{c}\text { Obsada cebuli } \\
\text { w rzędach } \\
\text { Density of onion } \\
\text { in rows } \\
{[\%]}\end{array}$ & $\begin{array}{c}\text { Zachwaszczenie wtórne } \\
\text { Secondary weed } \\
\text { infestation } \\
{[\%]}\end{array}$ \\
\hline Pendimethalin $\left(T_{1}\right)+$ glyphosate $\left(T_{2}\right)$ & $1155+720$ & 86,5 & 97,7 & 31,6 \\
\hline $\begin{array}{l}\text { Pendimethalin }\left(\mathrm{T}_{1}\right)+\text { glyphosate }\left(\mathrm{T}_{2}\right) \\
+ \text { pielenia mechaniczne }- \text { mechanical } \\
\text { treatments }(2 \times)\end{array}$ & $1155+720$ & 90,7 & 97,7 & 14,1 \\
\hline Glyphosate $\left(T_{2}\right)+$ oxyfluorfen $\left(T_{3}, T_{4}\right)$ & $720+7,2+12$ & 60,8 & 96,0 & 39,4 \\
\hline $\begin{array}{l}\text { Glyphosate }\left(\mathrm{T}_{2}\right)+\text { oxyfluorfen }\left(\mathrm{T}_{3}, \mathrm{~T}_{4}\right) \\
+ \text { pielenia mechaniczne }- \text { mechanical } \\
\text { treatments }(2 \times)\end{array}$ & $720+7,2+12$ & 82,1 & 97,6 & 19,9 \\
\hline Glyphosate $\left(\mathrm{T}_{2}\right)+$ bromoxynil $\left(\mathrm{T}_{3}\right)$ & $720+100$ & 75,7 & 97,4 & 40,2 \\
\hline $\begin{array}{l}\text { Glyphosate }\left(\mathrm{T}_{2}\right)+\text { bromoxynil }\left(\mathrm{T}_{3}\right) \\
+ \text { pielenia mechaniczne }- \text { mechanical } \\
\text { treatments }(2 \times)\end{array}$ & $720+100$ & 91,0 & 98,2 & 16,9 \\
\hline $\begin{array}{l}\text { Glyphosate }\left(\mathrm{T}_{2}\right) \\
+ \text { bromoxynil }\left(\mathrm{T}_{5}, \mathrm{~T}_{6}, \mathrm{~T}_{7}\right)\end{array}$ & $\begin{array}{c}720+ \\
100+150+200 \\
\end{array}$ & 70,3 & 97,4 & 24,7 \\
\hline $\begin{array}{l}\text { Glyphosate }\left(\mathrm{T}_{2}\right) \\
+(\text { bromoxynil }+ \text { pendimethalin })\left(\mathrm{T}_{5}\right) \\
+ \text { bromoxynil }\left(\mathrm{T}_{6}, \mathrm{~T}_{7}\right)\end{array}$ & $\begin{array}{c}720+ \\
(100+990) \\
150+200\end{array}$ & 89,4 & 98,4 & 22,3 \\
\hline Pielenie ręczne - Hand weeding & - & 95,4 & 98,6 & 0 \\
\hline Kontrola-Check & - & 49,7 & 93,5 & 45,8 \\
\hline
\end{tabular}

$\mathrm{T}_{1}-$ po siewie - after sowing; $\mathrm{T}_{2}-2-3$ dni przed wschodami $-2-3$ days before emergence; $\mathrm{T}_{3}-\mathrm{w}$ fazie liścieni- 1 liścia - at cotyledon -1 leaf stage; $\mathrm{T}_{4}-$ po 5-7 dniach od $\mathrm{T}_{3}-5-7$ days after $\mathrm{T}_{3} ; \mathrm{T}_{5}-\mathrm{w}$ fazie 1-2 liści - at 1-2 leaves stage; $\mathrm{T}_{6}-$ po 8 dniach od $\mathrm{T}_{5}-8$ days after $\mathrm{T}_{5} ; \mathrm{T}_{7}-$ po 8 dniach od $\mathrm{T}_{6}-$ 8 days after $\mathrm{T}_{6}$ treament

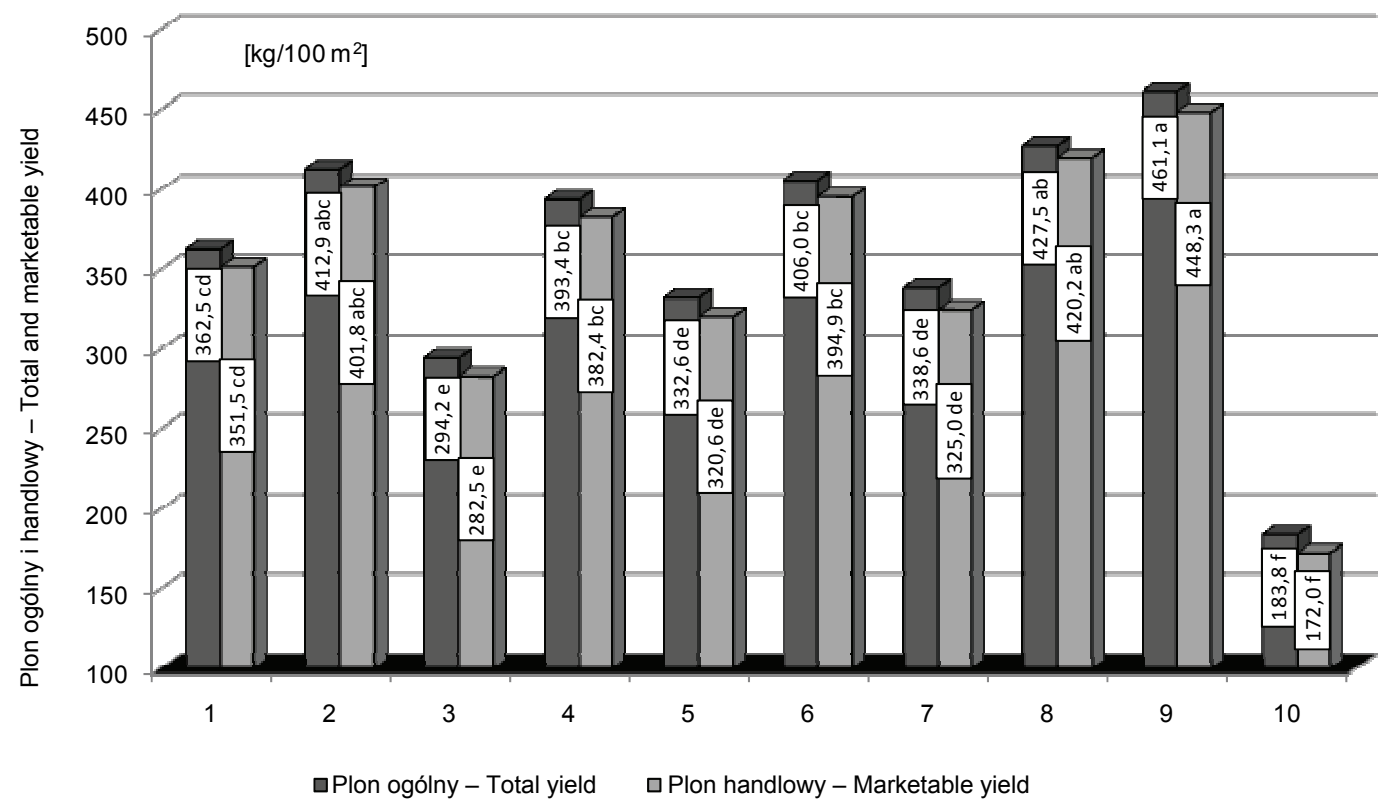

1 - Pendimethalin $-1155 \mathrm{~g}+$ glyphosate $-720 \mathrm{~g} ; 2$ - Pendimethalin $-1155 \mathrm{~g}+$ glyphosate $-720 \mathrm{~g}+$ pielenia mechaniczne - mechanical treatments; 3 - Glyphosate $-720 \mathrm{~g}+$ oxyfluorfen $(2 \times)-7,2+12 \mathrm{~g} ; 4$ - Glyphosate $-720 \mathrm{~g}+$ oxyfluorfen $(2 \times)-7,2+12 \mathrm{~g}+$ pielenia mechaniczne - mechanical treatments; 5 - Glyphosate $-720 \mathrm{~g}+$ bromoxynil $-100 \mathrm{~g} ; 6-$ Glyphosate $-720 \mathrm{~g}+$ bromoxynil $-100 \mathrm{~g}+$ pielenia mechaniczne - mechanical treatments; 7 - Glyphosate $-720 \mathrm{~g}+$ bromoxynil $(3 \times)-100+150+200 \mathrm{~g} ; 8-$ Glyphosate $-720 \mathrm{~g}+($ bromoxynil $-100 \mathrm{~g}+$ pendimethalin $-990 \mathrm{~g}$ ) + bromoxynil $(2 \times)-150+200 \mathrm{~g} ; 9$ - Pielenie ręczne - Hand weeding; $10-$ Kontrola - Check

Wartości oznaczone tymi samymi literami nie różnią sie istotnie przy $\alpha=0,05$ - Values with the same letter do not differ significantly at $\alpha=0.05$

Rys. 1. Plony cebuli, w zależności od metody ochrony przed chwastami (średnie z lat 2010-2012)

Fig. 1. Yields of onion, depending on weed management method (means for 2010-2012) 
Najwyższy plon ogólny $\left(461,1 \mathrm{~kg} / 100 \mathrm{~m}^{2}\right)$ i handlowy $\left(448,3 \mathrm{~kg} / 100 \mathrm{~m}^{2}\right)$ uzyskano $\mathrm{w}$ cebuli pielonej ręcznie. W doświadczeniach przeprowadzano od 4 do 5 pieleń ręcznych, w zależności od roku. Anyszka i wsp. (2012) donoszą, że pielenie ręczne najkorzystniej wpływało też na plonowanie papryki w uprawie polowej.

Nieznacznie niższe plony, w porównaniu do pielenia ręcznego, zanotowano w cebuli odchwaszczanej przed wschodami glifosatem i po wschodach bromoksynilem, stosowanym $\mathrm{w}$ trzech zabiegach, $\mathrm{z}$ dodatkiem pendimetaliny w czasie pierwszego opryskiwania. Najsłabiej plonowała cebula traktowana przed wschodami glifosatem, a po wschodach oksyfluorofenem w obniżonych dawkach. Dawki oksyfluorofenu (7 i $12 \mathrm{~g} / \mathrm{ha}$ ), obniżone w stosunku do dawki zalecanej, dobierano pod kątem przydatności do systemu odchwaszczania, uwzględniającego zabiegi mechaniczne. Stosowanie środka w tak niskich dawkach, tylko w dwóch zabiegach, jest niewystarczające dla skutecznego zniszczenia chwastów i wpływa na zmniejszenie plonów. W połączeniu z pieleniem mechanicznym może spowodować dobre zniszczenie chwastów i zwiększenie plonów. Pałczyński i Dobrzański (2007) podają, że stosowanie tak niskich dawek oksyfluorofenu wymaga wykonania 4-6 zabiegów tym środkiem.

Zabiegi mechaniczne, wykonywane po zastosowaniu herbicydów, bardzo korzystnie wpływały na wysokość plonów cebuli (rys. 1). We wszystkich obiektach, w których stosowano herbicydy i wykonywano pielenie mechaniczne plony były znacznie wyższe od plonów uzyskanych po użyciu samych herbicydów i istotnie wyższe od plonów z kontroli. Największy przyrost plonu ogólnego $(33,7 \%)$ i handlowego $(35,4 \%)$ cebuli zanotowano po użyciu glifosatu przed wschodami oraz oksyfluorofenu w fazie liścieni-1 liścia cebuli i po 5-7 dniach, uzupełnionym pieleniami mechanicznymi, w porównaniu do zastosowania samych herbicydów.
Badania wykazały, że zabiegi mechaniczne wykonywane po herbicydach, stosowanych po siewie i wcześnie po wschodach cebuli, stanowią istotny element ochrony przed chwastami, zwłaszcza w warunkach zmniejszającego się asortymentu środków chemicznych dopuszczonych w uprawie tej rośliny. Szersze wykorzystywanie zabiegów mechanicznych sprzyja opracowywaniu nowych rozwiazań technicznych i nowych narzędzi do zwalczania chwastów.

\section{Wnioski / Conclusions}

1. Zastosowanie herbicydów $\mathrm{w}$ połączeniu $\mathrm{z}$ zabiegami mechanicznymi, wykonywanymi w fazie 2-4 i 3-5 liści właściwych cebuli, powodowało bardzo silne ograniczenie zachwaszczenia pierwotnego i znacznie zmniejszało zachwaszczenie wtórne, w porównaniu do stosowania samych herbicydów.

2. Zabiegi mechaniczne, wykonywane po zastosowanych w początkowym okresie wegetacji cebuli herbicydach, wpływały na zwiększenie stopnia załamania szczypioru przed zbiorem.

3. Nie stwierdzono różnic w obsadzie cebuli między poszczególnymi systemami ochrony, najmniejsze zagęszczenie roślin obserwowano na kontroli.

4. Najwyższe plony cebuli uzyskano z poletek pielonych ręcznie oraz odchwaszczanych chemicznie z użyciem glifosatu przed wschodami, bromoksynilu z pendimetaliną w fazie 1-2 liści cebuli i samego bromoksynilu w późniejszych zabiegach.

5. Wyniki badań wskazują, że stosowanie herbicydów przed wschodami i wcześnie po wschodach, w połączeniu $\mathrm{z}$ zabiegami mechanicznymi, wykonywanymi od 2-4 liści cebuli, pozwala na skuteczne zniszczenie chwastów i uzyskanie wysokich plonów.

\section{Literatura / References}

Adamczewski K., Dobrzański A. 1997. Regulowanie zachwaszczenia w integrowanych programach ochrony roślin. [Weed control management in integrated crop protection]. Prog. Plant Prot./Post. Ochr. Roślin 37 (1): 58-66.

Adamczewski K., Dobrzański A. 2012. Przyszłość herbologii w zmieniającym się rolnictwie. [Future for weed science in changing agriculture]. Prog. Plant Prot./Post. Ochr. Roślin 52 (4): 867-878.

Anyszka Z., Golian J., Kohut M. 2012. Porównanie efektywności różnych metod ochrony przed chwastami papryki (Capsicum annum L.) w uprawie polowej. [Comparison the effectiveness of different methods of weed control in field cultivated pepper (Capsicum annum L.)]. Prog. Plant Prot./Post. Ochr. Roślin 52 (4): 879-884.

Autko A.A., Moisevich N.V. 2006. Technology of mechanized onion production in Belarus. Veg. Crops Res. Bull. 64: $107-115$.

Bond W., Grundy A.C. 2001. Non chemical weed management in organic farming systems. Weed Res. 41: 383-405.

Dobrzański A. 1994. Integracja ochrony warzyw przed chwastami z uwzględnieniem możliwości zmniejszenia zużycia herbicydów. Materiały 34. Sesji Nauk. Inst. Ochr. Roślin, cz. 1: 104-110.

Dobrzański A. 1998. Rola różnych metod ochrony przed chwastami w integrowanym systemie produkcji warzyw. s. 86-93. W: Materiały Ogólnopolskiej Konferencji Naukowej „Ekologiczne aspekty produkcji ogrodniczej”. Poznań, 17-18.11.1998. Wydawnictwo AR Poznań, 356 ss.

Dobrzański A. 1999. Ekologiczne podstawy ochrony przed chwastami. s. 8-29. W: „Ochrona warzyw przed chwastami”. PWRiL, Warszawa, 199 ss.

Dobrzański A., Adamczewski K. 2006. Perspektywy wykorzystania nowych narzędzi i maszyn do regulacji zachwaszczenia $\mathrm{w}$ integrowanej i ekologicznej produkcji roślinnej. [Progress in mechanical methods of weed management in integrated and organic farming systems]. Prog. Plant Prot./Post. Ochr. Roślin 46 (1): 11-18.

Dobrzański A., Adamczewski K. 2009. Niechemiczne metody zwalczania chwastów. Stan obecny i perspektywy. Ekspertyza dostępna w serwisie www.agengpol.pl [dostęp: 08.12.2009].

Dobrzański A., Pałczyński J., Anyszka Z., Ulińska Z. 1992. Możliwość obniżania dawek herbicydów w uprawie cebuli i fasoli przez zastosowanie metody dzielonej. Materiały 32. Sesji Nauk. Inst. Ochr. Roślin, cz. 2: 125-128. 
Fogelberg F., Kritz G. 1999. Intra-row weeding with brushes on vertical axes - factors influencing in-row soil height. Soil \& Tillage Res. 50: 149-157.

Mahmood Khokhar K., Mahmood T., Shakeel M., Farooq Chaudhry M. 2006. Evaluation of integrated weed management practices for onion in Pakistan. Crop Prot. 25: 968-972.

Pałczyński J., Dobrzański A. 2007. Reakcja cebuli i chwastów na mikrodawki oksyfluorofenu z adiuwantami. [The response of weeds and onion to microrates of oxyfluorfen with adjuvants]. Prog. Plant Prot./Post. Ochr. Roślin 47 (3): 224-228.

Pałczyński J., Dobrzański A., Anyszka Z. 2001. Weeds and drilled onion response to postemergence application of tank-mixture herbicides. Veg. Crops Res. Bull. 54 (1): 125-130.

Pałczyński J., Dobrzański A., Anyszka Z. 2002. Zwalczanie chwastów po wschodach cebuli mieszaninami różnych herbicydów. [Postemergence weed control with tank-mixture herbicides in drilled onion]. Prog. Plant Prot./Post. Ochr. Roślin 42 (2): $479-482$.

Pałczyński J., Dudek J. 2003. Reakcja cebuli i chwastów na chemiczne i mechaniczne odchwaszczanie w świetle dotychczasowych badań. Nowości Warzywnicze 36: 85-90.

Van der Weide R.Y., Bleeker P.O., Achten V.T.J.M., Lotz L.A.P., Fogelberg F., Melander B. 2008. Innovation in mechanical weed control in crop rows. Weed Res. 48: 215-224.

Zbytek Z., Talarczyk W. 2008. Nowe rozwiązania proekologicznych maszyn do mechanicznego zwalczania chwastów. s. $250-255$. W: „Poszukiwanie nowych rozwiązań w ochronie upraw ekologicznych” (E. Matyjaszczyk, red.). Inst. Ochr. Roślin, Poznań, 393 ss. 